\title{
Population Dynamics of Tuta absoluta (Meyrick, 1917) [Lepidoptera: Gelechiidae] With Different Traps Types in Open Areas of Şanlıurfa Province, Turkey
}

\author{
Abdurrahman AZLI ${ }^{1}$, Çetin MUTLU ${ }^{2 *}$
}

\begin{abstract}
Tomato is an important crop in Turkey, which is grown in greenhouses as well as in open fields. Tomato leafminer [Tuta absoluta (Meyrick, 1917)] is a serious pest of tomato production in the country. The residues of greenhouse tomato are thrown in nearby fields, which could result in significant populations of the pest. However, limited work has been done to assess the population dynamics of the pest in the fields adjacent to greenhouse or open field tomato production areas in Turkey. Therefore, the current study was conducted to determine the population dynamics of the pest in open fields near tomato production areas in Şanlıurfa province, Turkey during 2014-2015. Three different trap types (delta, water + pheromone and ferolite) were established in three different fields in the Harran plain of the province. The traps were established during the month of May and monitoring was continued until January. The pest population was monitored weekly during the whole study period. The population density of the pest reached to the highest level during September, and a continuous decline was noted afterward. The highest average number of adults trapped by ferolite traps were 278 adult week ${ }^{-1}$, whereas delta traps caught the lowest number of the adults $\left(60\right.$ adult week $\left.{ }^{-1}\right)$. The water pheromone traps also collected similar number of adults ( 79 adult week $^{-1}$ ) to delta traps. Overall, ferolite trap type exhibited higher efficacy in trapping and monitoring the adults compared to the rest of the trap types included in the study. The current study reveals that tomato residues could result in significant populations of the pest in the adjacent fields, which could negatively affect other crops. Therefore, the residues must be managed properly to avoid the pest outbreaks in adjacent areas of tomato production. Moreover, ferolite traps could be used effectively to manage the pest in tomato production areas.
\end{abstract}

Keywords: Tuta absoluta, population monitoring, Ferolite, delta, water pheromone trap

\footnotetext{
1 Abdurrahman AZLI (Orcid ID: 0000-0001-7076-4397), Harran University, Graduate School of Natural and Applied Sciences, Department of Plant Protection, Şanlıurfa, Turkey

2 Çetin MUTLU (Orcid ID: 0000-0003-4962-5506), Harran University, Faculty of Agriculture, Department of Plant Protection, Şanlıurfa, Turkey

*Sorumlu Yazar / Corresponding Author: Çetin MUTLU, e-mail: cetinmutlu21@ hotmail.com

This study is a part of Master thesis of Abdurrahman AZLI. The article was presented as an oral paper at the International Erciyes Agriculture, Animal \& Food Sciences conference held on 24-27 April 2019 in Kayseri.
} 


\section{INTRODUCTION}

Tomato, Lycopersicum esculentum (L.) is one of the economically important vegetable crops and widely cultivated in the world. It is among the highly consumed and traded products in the world (Hanson et al., 2001; Singh et al., 2014). It is grown in many countries of the world in open areas and greenhouses. Tomato is grown in open fields and greenhouses in many regions of Turkey which have suitable climatic conditions for its production. Turkey ranks $4^{\text {th }}$ globally in terms of tomato production, whereas occupies first position in the export of tomato sauce and fresh tomato (FAO, 2014). The southeastern Anatolia region has $15 \%$ share in the tomato production of Turkey. Şanlıurfa is situated in southeastern Anatolia region whose share in the tomato production of the region has increased considerably with the increase of irrigated areas. Tomato was produced on 4.232 hectares with 231.000 tons production during 2018 in Şanliurfa province. (TÜİK, 2019). Several diseases, pests and weeds are the major harmful factors that negatively affect tomato production in Turkey. Of these factors, harmful insect species exert the highest negative consequences to tomato production in the country. More than 70 pest species are known to infest tomato crop, whereas Whitefly (Bemisia tabaci Genn.) (Hemiptera: Aleyrodidae), Leaf gallery fly (Liriomyza trifolii Burgess) (Diptera: Agromyziidae), Red spider (Tetranychus cinnabarinus (Boisd) (Acari: Tetranychida) and tomato leafminer (Tuta absoluta) (Meyrick) (Lepidoptera: Gelechiidae) are regarded as the major pests of the crop (Uygun et al., 1998). However, leafminer is the most important pest species that threatens tomato cultivation globally (Lopez, 1991; Desneux et al., 2010; Guillemaud et al., 2015).

Tomato leafminer (Tuta absoluta) is a very destructive and hard to control pest of tomato (Lopez, 1991; Picanço et al., 1998; Desneux et al., 2010; Guillemaud et al. 2015). The pest originates in South America, from where it spread to Mediterranean region, continental Europe, the Middle East and Africa. Currently, it is a serious threat for tomato production in Europe, Africa and several Asian countries such as India and China and Turkey (Souza et al., 1983; Desneux et al., 2011; Kalleshwaraswamy et al. 2015). Tuta absoluta has evolved resistance to several pesticides due to continuous use of pesticides with the same mode of action. Tuta absoluta could also feed on several solanaceous species including eggplant, pepper, tobacco, potato and many more (Moore, 1983; Salazar and Araya, 1997; Siqueira et al.,2000; Salazar and Araya, 2001; Siqueira et al., 2001). This insect feeds on almost every part of the plant and forms galleries while feeding on the plant's inner tissues (Lopez, 1991; Souza et al., 1992; Miranda et al., 1998). Thus, it can cause plant mortality and is costly and difficult to control with chemical sprays.

The pest was first recorded in Turkey during 2009 from tomato production areas of Urla district in İzmir province (Kılıç, 2010). The pest was then reported from Kumluca district of Antalya province which is famous for greenhouse farming in Turkey during 2010 (Erler et al., 2010). The pest has a high damage potential; therefore, spread in a short period of time and became the main pest in open field and greenhouse tomato cultivation areas. Even if intensive pesticides are applied by using various pesticides against pests, the damage can be seen in tomato fruits (Moore, 1983). In recent years, damage up to $100 \%$ has been observed in open field and green house tomato production areas in the Harran plain of Şanlıurfa province.

Chemical control method used to manage the pest in greenhouses and open tomato production areas is not enough to control of the pest (unpublished field observation). The use of modern techniques as well as a conscious pest 
control program is mandatory for economic agricultural production. Selection of appropriate control method and time is the most important factor in the integrated control principles. Tuta absoluta is managed in southeastern Anatolia region by cultural, chemical, biological and biotechnical control methods (Anonymous, 2008).

It is a common practice in greenhouse production areas of Turkey to throw the tomato crop residues in adjacent areas for the sowing of succeeding crop. These residues could harbor the pest, which could shift to other crops. In recent years, use of sexually attractive traps against various pests has been increased considerably within the scope of biotechnical control. Of the sexually attractive traps, delta, water + pheromone and ferolite trap types are extensively used. As these traps used to attract harmful adults, some studies have been conducted in both open fields and greenhouses in Turkey and other countries and different results have been obtained. However, there is no study on the effectiveness of sexually attractive traps in open areas adjacent to tomato areas. This study was carried out between 2014-2015 in order to determine the population dynamics and correct trap type (Delta, water + pheromone and Ferolite) for population follow-up and effective biotechnical control of T. absoluta in open areas outside the tomato production area in Şanliurfa province.

\section{MATERIALS AND METHODS}

\section{Experimental site description}

The current study was conducted in Karaali and Tuzlaca villages situated in the Harran plain of Şanlıurfa province, Turkey. Three different fields were selected in these villages adjacent to greenhouse tomato production areas and different traps were installed in the selected fields for population dynamics studies. The geographic coordinates of field 1,2 and 3 were $37.0016^{\circ} \mathrm{N}, 39.166472{ }^{\circ} \mathrm{S}$, $37.007581{ }^{\circ} \mathrm{N}, 39.169422^{\circ} \mathrm{S}$ and $37.004621^{\circ} \mathrm{N}$, $39.160936^{\circ} \mathrm{S}$, respectively (Figure 1).

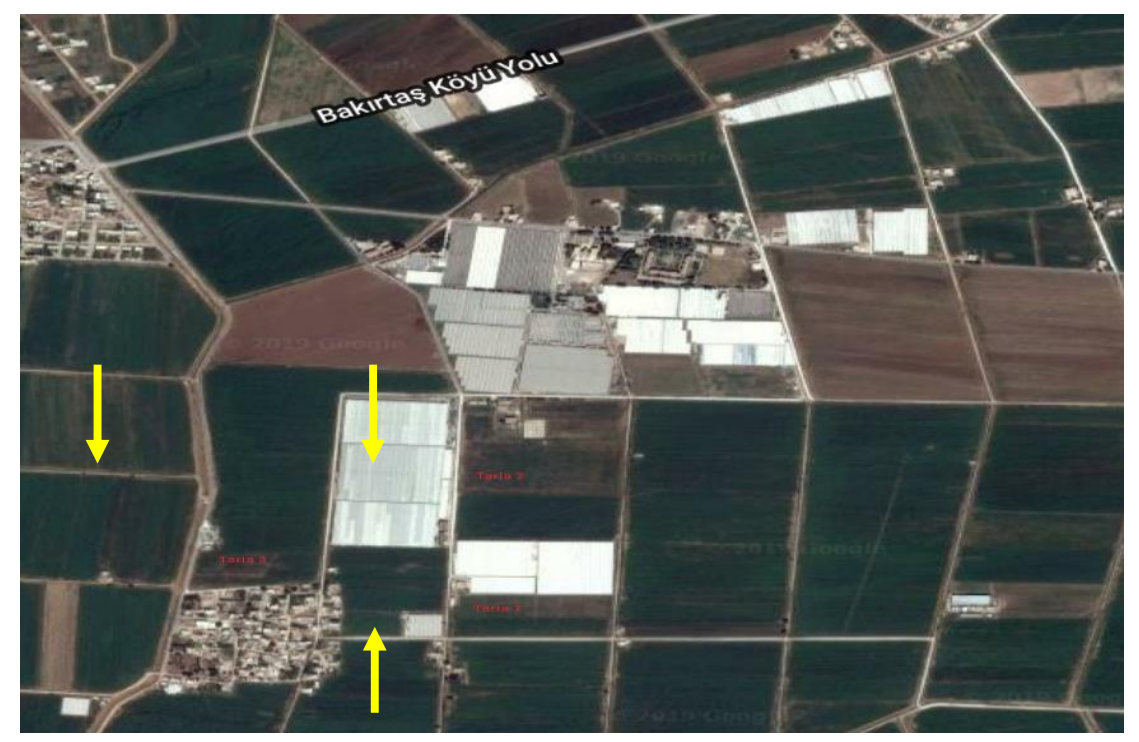

Figure 1. Location of different study sites in Şanllurfa province, Turkey included in the experiment

\section{Trap types}

Three different trap types, i.e., delta, water + pheromone and ferolite (light + pheromone) were used in the current study. The traps were suspended in the selected fields at specific heights according to the recommendations of various earlier studies. The traps were suspended in the selected fields on 14.05.2014. A minimum 
500-meter distance was maintained between the selected fields. The traps were suspended in three replications and at least 50-meter isolation distance was maintained between the replications. Delta-type traps were suspended at 1.5 meter above the soil. Water + pheromone trap and ferolite traps were suspended 0.6 meter above the soil. The first pest count was conducted two days after the suspension date of the traps.

\section{Determination of Population Dynamics of Tuta absoluta}

For data collection presence of T. absoluta was detected first by following the traps and then regular pest counts were made at one-week interval until the termination of the experiment. The pheromone capsules used in the traps were replaced with new ones every 4 weeks considering the effect of hot weather and adverse effects of climatic conditions. The replaced old capsules were removed from the study area to prevent any negative consequence. After weekly counts, water + pheromone trap and ferolite type traps were cleaned and prepared again. Delta type traps were replaced with new ones after counting every week. When replacing the adhesive plate, the pheromone capsule was removed with a spatula and taken into the new adhesive plate.

The site and traps were checked every 2 days from the beginning of the study until termination of the experiment to avoid any negative conditions that would affect the study. The experiment was terminated on 30.01.2015 as no adults of the pests were detected. In addition, daily average temperature and relative humidity values were recorded with the help of Climate meter (HOBO) installed on the selected fields and is represented in Figure 2.

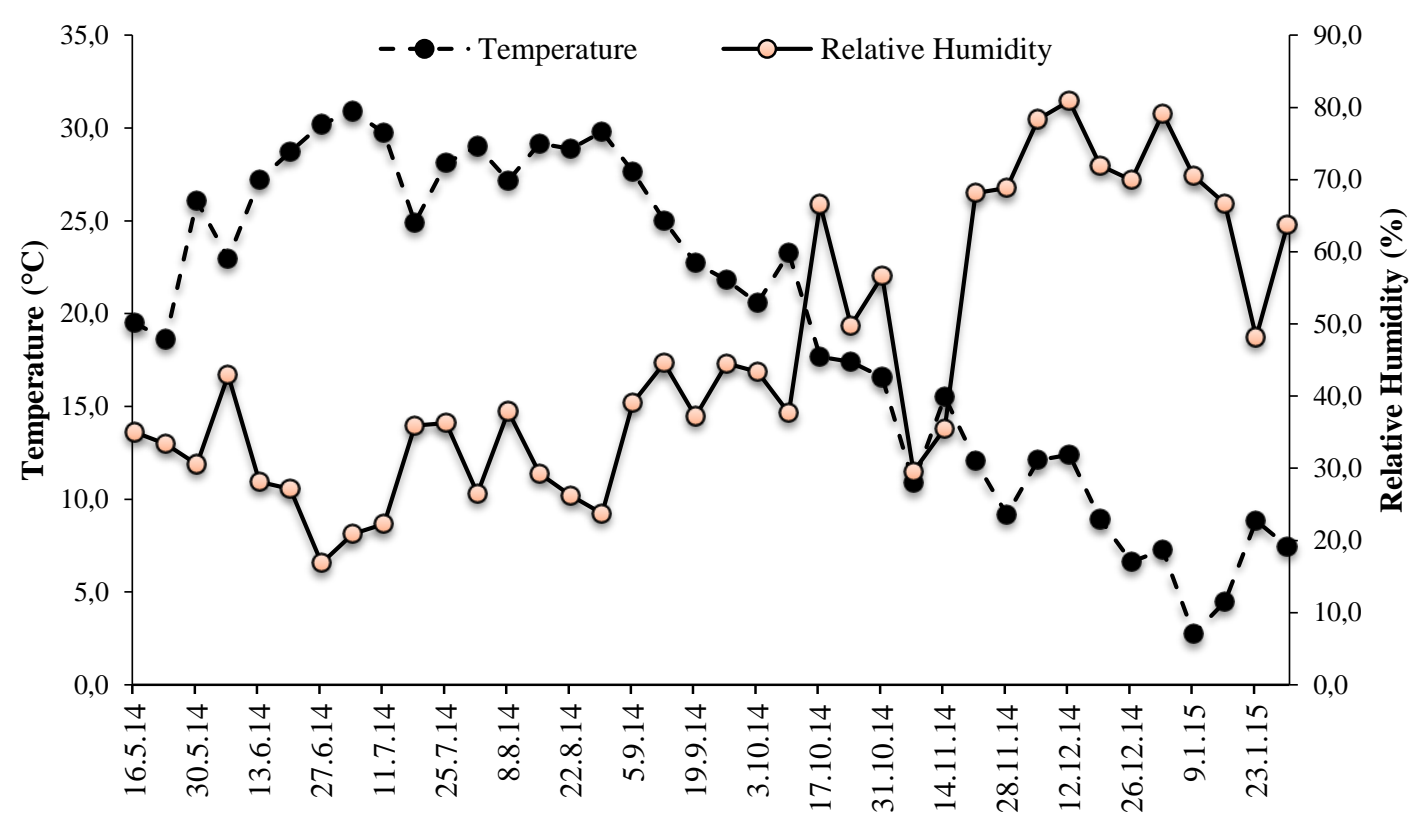

Figure 2. Climatic conditions (temperature and relative humidity) pervailing at the study sites during the experiment

\section{Statistical analysis}

The data collected on number of adults trapped by each trap were analyzed by one-way analysis of variance (ANOVA) (Steel et al.,
1997). Normality in the data was tested prior to ANOVA, which indicated a non-normal distribution. Therefore, data were arcsine transformed to meet the normality assumption of 
ANOVA. Means of trap types were grouped according to $95 \%$ significance level using least significant difference test. Statistical analysis was performed on SPSS (version 21.0) computer program (IBM, 2012). Graphical representation of the periodic climatic and pest count data was accomplished by using Microsoft Excel program.

\section{RESULTS AND DISCUSSION}

The population density started to increase in July when average temperature and relative humidity were $28.4{ }^{\circ} \mathrm{C}$ and $28.9 \%$, respectively in all study sites. Similarly, the temperature and relative humidity in August were $28.8{ }^{\circ} \mathrm{C}$ and $28.7 \%$, respectively. The first pest count in the traps was done on 16.05.2014 in order to determine the initiation of pest outflow. While no adult was caught by delta type trap, 11 adults were caught by water + pheromone trap during first count. One week after the first count, 7 adults were caught by delta trap. Ferolite type traps were suspended on 13.06.2014 due to in the delivery of traps. Therefore, the first pest count in ferolite traps one week after the suspension and 186 adults were recorded during the first count (Figure 3).

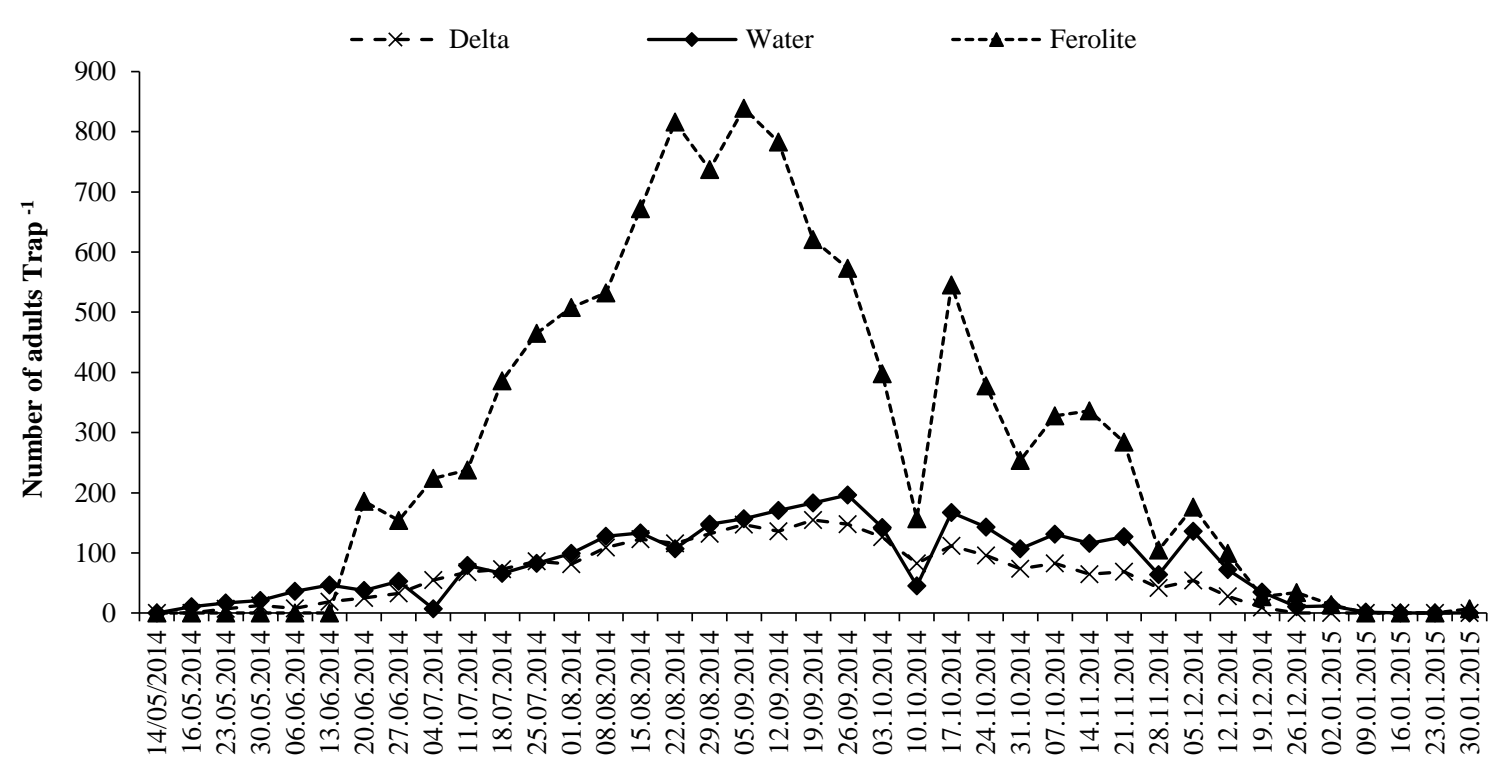

Figure 3. The number of insects trapped by different trap types at first study site

The population density of tomato leafminer increased with time, reached to the highest level and then started declining. Two different peaks of the highest density of tomato leafminer were observed for field 1 for delta trap. The first peak with 147 adults week ${ }^{-1}$ was noted on 05.09.2014, whereas the second peak with 155 adults week ${ }^{-1}$ on 19.09.2014. Similarly, two different peaks were observed for water + pheromone trap. The first peak with 133 adults week $^{-1}$ was noted on 15.08.2014, while the second peak with 196 adults week $^{-1}$ was observed on 26.09.2014. In the ferolite traps, the first and second peak with 816 and 839 adults week $^{-1}$ was recorded on 22.08.2014 and 05.09.2014, respectively (Figure 3 ).

In the second field 9 and 21 adults were caught by delta and water + pheromone traps, respectively during first count. However, due to late suspension and first pest count of ferolite traps, 96 adults were caught during the first pest count. The highest population density was noted during September in field 2. Similar to field 1, two different peaks of population density were 
noted for each trap type in field 2 with ferolite trap as an exception where only one peak was recorded. The first and second peak in delta type trap with 157 and 176 adults week ${ }^{-1}$ was recorded on 29.08.2014 and 19.09.2014, respectively. Likewise, the first and second peak in the water + pheromone trap was noted on 01.08.2014 and 12.09.2014 with 173 and 248 adults week $^{-1}$, respectively. The only peak in ferolite trap was observed on 19.09.2014with 856 adults week $^{-1}$ (Figure 4). Sudden fluctuations were observed in the population density during the monitoring period. These fluctuations were the result of overflow problem in water + pheromone and ferolite trap due to heavy rainfall (Figure 4).

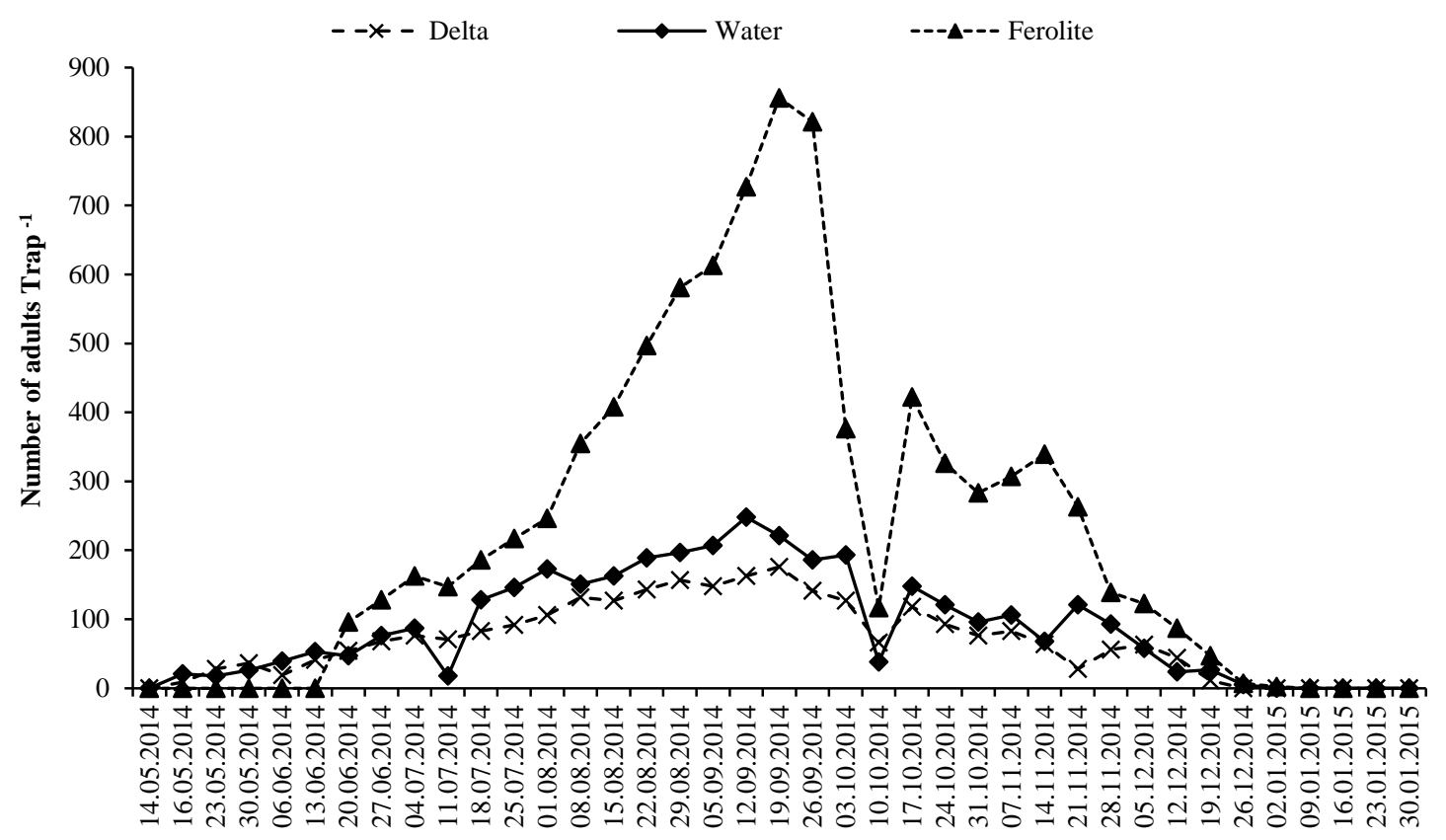

Figure 4. The number of insects trapped by different trap types at second study site

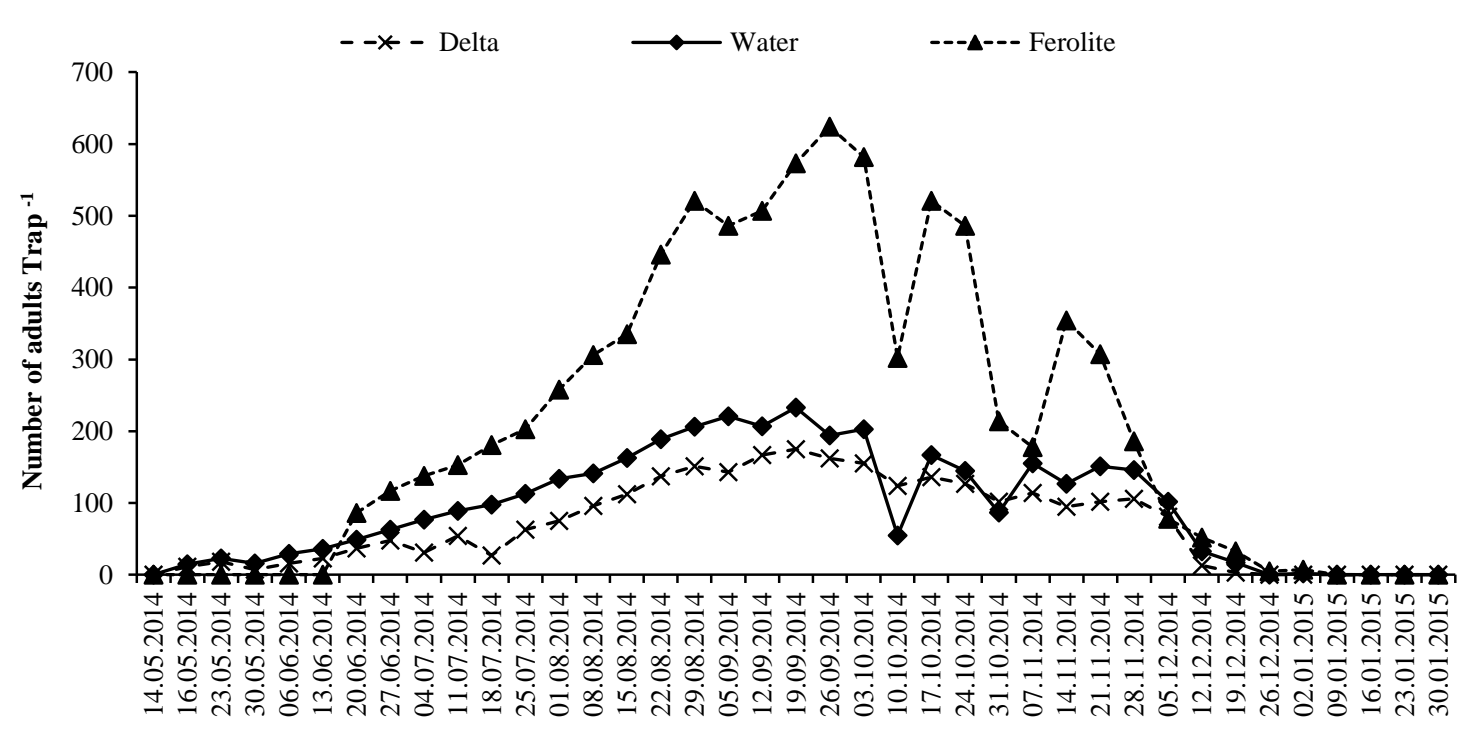

Figure 5. The number of insects trapped by different trap types at third study site 
Regarding field 3, 11 and 15 adults were caught be delta and water + pheromone traps during the first count. Similarly, ferolite traps caught 86 adults during the first pest count because of late suspension and delay in the first pest count. Two different population density peaks were noted for each trap type in field 3 . The first and second peak of delta type trap was observed on 29.08.2014 and 19.09.2014 with 151 and adults week $^{-1}$. Similarly, first and second peak for water + pheromone trap was noted on 05.09.2014 and 19.09.2014 with 211 and 233 adults week ${ }^{-1}$, respectively. Likely, the first and second peak of ferolite traps was recorded on 29.08.2014 and 26.09.2014 with 521 and 624 adults week $^{-1}$, respectively (Figure 5).
The population density reached to the highest-level during September and then a constant decline was noted in field 3. The sudden fluctuations in the population density were also recorded in field 3 which were attributed to heavy rainfall-induced overflow in the traps.

The data of weekly pest counts was analyzed to know which trap type caught the highest number of adults. The results indicated that ferolite trap caught the highest number of tomato leafminer adults compared to the rest of the trap types included in the study. Delta and water+ pheromone traps caught statistically similar number of adults (Table 1).

Table 1. Efficacy of different trap types against Tuta absoluta adults at three diffeerent study sites

\begin{tabular}{lccc}
\hline Trap type & \multicolumn{3}{c}{ Number of adults trapped trap $^{-1}$} \\
\hline & Field 1 & Field 2 & Field 3 \\
\hline Delta & $60.89 \pm 8.21 \mathrm{a}$ & $69.20 \pm 8.62 \mathrm{a}$ & $69.51 \pm 9.51 \mathrm{a}$ \\
Water + Pheromone & $79.23 \pm 9.80 \mathrm{a}$ & $89.53 \pm 12.08 \mathrm{a}$ & $94.51 \pm 12.19 \mathrm{a}$ \\
Ferolite & $278.87 \pm 43.25 \mathrm{~b}$ & $227.66 \pm 38.74 \mathrm{~b}$ & $211.25 \pm 33.16 \mathrm{~b}$ \\
\hline
\end{tabular}

Any two means sharing the same letter within a column or a row are statistically non-significant $(\mathrm{P}>0.01)$

Significant population density of tomato leafminer was noted in open areas adjacent to tomato fields in the studied region. The pest population reached to the highest-level during September. It was observed that the average temperature and relative humidity varied between $20-30{ }^{\circ} \mathrm{C}$ and $35-45 \%$ during the peak density period (Figure 2). Bayram et al. (2017) also reported similar results as of current study. The highest (163) number of T. absoluta adults trap $^{-1}$ were observed in Diyarbakır province during July when temperature and relative humidity were $31.7{ }^{\circ} \mathrm{C}$ and $18.3 \%$, respectively. Similarly, the second highest number of adults trap $^{-1}$ were noted during August where temperature and relative humidity were $32.9{ }^{\circ} \mathrm{C}$ and $18.7 \%$, respectively (Bayram et al., 2017).

A continuous increase in the population density of tomato leafminer was noted in the current study, which reached to the highest level during September and then started declining. Significant differences were noted among different trap types for number of adults caught at different intervals. Overal, ferolite trap caught higher number of tomato leafminer adults compared to the rest of the trap types included in the study. Several studies from Turkey as well as other parts of the world have reported similar results as of current study. For example, Filho et al. (2000) reported that pheromone trap caught 869 adults trap ${ }^{-1}$ form tomato crop cultivated in open areas. However, Ferrara et al. (2001) reported a lower number of adults (201) caught by pheromone trap and an increase in the number of adults caught trap ${ }^{-1}$ was reported with increasing pheromone dose. Similary, Aksoy and Karaca (2015) recorded 351-483 adults week $^{-1}$ from open field and green house tomato 
cultivation areas, respectively form Uşak province.

In Adana province, pheromone traps caught 869 individuals trap $^{-1}$ from open field tomatoes (Portakaldalı et al., 2013). In another study conducted in open-field tomato production areas in Şanliurfa in 2010-2011, the highest number of individuals caught by pheromone traps were 370 to 978 (Mamay and Yanık, 2012). Özkan et al. (2017) also reported similar results as of current study from Konya province of Turkey where pheromone traps caught 640 and 626 adults week $^{-1}$, whereas ferolite type traps caught approximately twice adults, i.e., 1250 and 1525 adults week ${ }^{-1}$ as of pheromomne traps. Furthermore, ferolite traps have been reported as more effective than pheromone traps as they attract both male and female individuals.

The first adult appeared during the second week of May in the traps, whereas population density reached its highest-level during September and October though it decreased from time to time. Similarly, Mamay and Yanık (2012) reported first adult flight of tomato leafminer during first week of May in sexually attractive pheromone traps. The population density reached the highest-level during July, August, September and October.

One of the most important reasons of continuous increase in population density of tomato leafminer during summer despite negative environmental and climatic conditions is the fact that climatic conditions are suitable for the development of the pest in greenhouses. Thus, the pest spreads from the greenhouses to open fields, which increases population density. Similarly, Karut et al. (2011) reported an increase in the population density of the pest in greenhouses from the end of May as temperature starts to increase in greenhouses.

\section{CONCLUSION}

The population density of tomato leafminer the greenhouses situated in the study area, i.e., Karaali village of Şanlıurfa province increases significantly after the harvest of tomato crop as producers do not use any precautionary measures against tomato leafminer in greenhouses after the production season ends in June and July. Moreover, keeping residues in the greenhouses instead of disposing off further increases the population density of tomato leafminer in the greenhouses. It is thought proper disposal of plant residues would prevent the increase of tomato leafminer by preventing the transition from greenhouses to open field tomato fields. Furthermore, ferolite traps could be used to manage the pest in greenhouses as well as open areas of tomato production.

\section{REFERENCES}

Aksoy A, Karaca İ, 2015. Uşak İlinde Yoğun Domates Yetiştiriciliği Yapılan Alanlarda (Hatipler ve Koyunbeyli) Sera ve Açık Alan Koşullarında Domates Yaprak Galeri Güvesinin Popülasyon Gelişimi. Süleyman Demirel University Journal of Natural and Applied Sciences, 19(3): 80-84.

Anonymous, 2008. Zirai Mücadele Teknik Talimatları. Cilt: 3. T.C. Tarım ve Köyişleri Bakanlığı Tarımsal Araştırmalar Genel Müdürlüğü (TAGEM), Ankara, $332 \mathrm{~s}$.

Bayram Y, Duman M, Buyuk M, Mutlu C, 2017. Efficiency of pheromone water traps and life cycle of Tuta absoluta (lepidoptera: Gelechiidae) in Diyarbakir Province, Turkey. Fresenius Environmental Bulletin, 26: 531-538.

Desneux N, Wajnberg E, Wyckhuys KA, Burgio G, Arpaia S, Narváez-Vasquez CA, Nicolas Cabrera JG, Ruescas DC, Tabone E, Frandon J, Pizzol J, Poncet C, Cabello C, Urbaneja A, 2010. Biological invasion of European tomato crops by Tuta absoluta: ecology, geographic expansion and prospects for biological control. Journal of pest science, 83(3): 197-215. 
Desneux N, Luna M. G, Guillemaud T, Urbaneja A, 2011. The invasive South American tomato pinworm, Tuta absoluta, continues to spread in Afro-Eurasia and beyond: the new threat to tomato world production. Journal of Pest Science, 84(4): 403-408.

Erler F, Can M, Erdoğan M, Ateş AO, Pradier T, 2010. New record of Tuta absoluta (Meyrick) (Lepidoptera: Gelechiidae) on greenhouse-grown tomato in Southwestern Turkey (Antalya). Journal of Entomological Science, 45(4): 392-393.

FAO, 2014. Food and Agriculture Organization, food and agriculture data, http://www.fao.org/faostat/en/\#home (Date of access: 05 April 2019).

Ferrara FA, Vilela EF, Jham GN, Eiras ÁE, Picanço MC, Attygalle AB, Salvatos Frighetto, RTS, Meinwald J, 2001. Evaluation of the synthetic major component of the sex pheromone of Tuta absoluta (Meyrick) (Lepidoptera: Gelechiidae). Journal of Chemical Ecology, 27(5): 907917.

Filho MM, Vileda EF, Jham G, Nattygalle A, Svatoś A, Meinwald J, 2000. Initial Studies of Mating Disruption of the Tomato Moth, Tuta absoluta Lepidoptera: Gelechiidae) Using Synthetic Sex Pheromone. Journal of Brasil Cemical Society, 11: 621-628.

Guillemaud T, Blin A, Le Goff I, Desneux N, Reyes M, Tabone E, Tsagkarakou A, Niño L, Lombaert E, 2015. The tomato borer, Tuta absoluta, invading the Mediterranean Basin, originates from a single introduction from Central Chile. Scientific reports, 5: 8371.

Hanson P, Chen JT, Cou CG, Morris R, Opena RT, 2001. Tomato production. Asian Vegetable Research and Development Center (AVRDC), 62: 8-9.
Kalleshwaraswamy C M, Murthy M S, Viraktamath CA, Kumar NK, 2015. Occurrence of Tuta absoluta (Lepidoptera: Gelechiidae) in the Malnad and HyderabadKarnataka Regions of Karnataka, India. Florida Entomologist, 98(3): 970-972.

Karut K, Kazak C, Döker I, Ulusoy MR, 2011. Pest status and prevalence of tomato moth Tuta absoluta (Meyrick 1917) (Lepidoptera: Gelechiidae) in tomato growing greenhouses of Mersin. Turkish Journal of Entomology, 35(2): 339-347.

Kılıç T, 2010. First record of Tuta absoluta in Turkey. Phytoparasitica, 38 (3): 243-244.

Lopez E, 1991. Polilla del tomate: Problema cri'tico para la rentabilidad del cultivo de verano, Empresa y Avance Agricola, 1: 6-7.

Mamay M, Yanik E, 2012. Determination of adult population development of Tomato leafminer [Tuta absoluta (Meyrick) (Lepidoptera: Gelechiidae)] in tomato growing areas in Şanlıurfa. Turkish Bulletin of Entomology, 2(3): 189-198.

Miranda MMM, Picanço M, Zanuncio JC, Guedes RNC, 1998. Ecological life table of Tuta absoluta (Meyrick) (Lepidoptera: Gelechiidae). Biocontrol Science and Technology, 8: 597606.

Moore JE, 1983. Control of tomato leafminer (Scrobipalpula absoluta) in Bolivia. Tropical Pest Management, 29: 231-238.

Özkan Z, Ünlü L, Öğür E, 2017. Comparison of the Efficiency of Pheromone and Pherolite Traps Used Against Tomato Moth (Tuta absoluta Meyrick) in Greenhouse Tomato Growing. Harran Journal of Agricultural and Food Science, 21(4): 394-403.

Picanço MC, Leite GLD, Guedes RNC, Silva EA,1998. Yield loss in trellised tomato affected by insecticidal sprays and plant spacing. Crop Protection 17: 447-452. 
Portakaldalı M, Öztemiz S, Kütük H, 2013. Population monitoring of Tuta absoluta Meyrick) (Lepidoptera: Gelechiidae) and its natural enemies in open field tomatoes cultivation in Adana. Journal of Agricultural Faculty of Bursa Uludag University, 27(2): 45-54.

Salazar ER, Araya JE, 1997. Detección de resistencia a insecticidas en la polilla del tomate. Simiente 67:8-22.

Salazar ER, Araya JE, 2001. Respuesta de la polilla del tomate, Tuta absoluta (Meyrick), a insecticidas en Arica. Agricultura Técnica, 61: 429-435.

Singh T, Singh N, Bahuguna A, Nautiyal M, Sharma VK, 2014. Performance of Tomato (Solanum lycopersicum L.) hybrids for growth, yield and quality inside polyhouse under mid hill condition of Uttarakhand. American Journal of Drug Discovery and Development, 4: 202-209.

Siqueira HAD, Guedes RN, Fragoso DB, Magalhães LC, 2001. Abamectin resistance and synergism in brazilian populations of Tuta absoluta (Meyrick) (Lepidoptera: Gelechiidae). International Journal of Pest Management, 47: 247-251.

Siqueira HAD, Guedes RN, Picanço MC, 2000. Insecticide resistance in populations of Tuta absoluta (Lepidoptera:Gelechiidae). Agricultural and Forest Entomology, 2: 147153.
Souza JC, Reis PR, de Padua Nacif A, Gomes JM, Salgado LO, 1983. Controle da traça-dotomateiro. Histórico, reconhecimento, biología, prejuízos e controle. Belo Horizonte, Brazil: Empresa de Pesquisa Agropecuária de Minas Gerais, 15

Souza JC, Reis PR, Salgado LO,1992. Traça Do Tomateiro: Histórico, Reconhecimento, Biologia, Prejuízos E Controle. EPAMIG. Boletim Técnico, 57: 32p.

Steel, RG, Torrie JH, Dickey DA, 1997. Principles and procedures of statistics: A biological approach. McGraw-Hill., 663 p.

TÜIK, 2019. The Statistical Institute of the Republic of Turkey, Vegetal production statistics.

https://biruni.tuik.gov.tr/medas/?kn=92\&loc ale $=\operatorname{tr}$ (Date of access: 21 June.2019).

Uygun N, Ulusoy MR, Başpınar H, 1998. Sebze Zararlıları. Çukurova Üniversitesi Ziraat Fakültesi Genel Yayın No:213, 168 s, Adana-Türkiye. 